\title{
Strategies for Settler Decolonization: Decolonial Pedagogies in a Popular Music Analysis Course
}

Robin Attas

Queen's University

\begin{abstract}
Canadian institutions of higher education are grappling with decolonization, particularly with how to move beyond decolonial and settler colonial theory and the Truth and Reconciliation Commission of Canada's Calls to Action to practical and specific strategies for meaningful change in the classroom. To that end, this paper offers a case study of a settler instructor's process of decolonization in a popular music analysis course and describes a variety of methods for decolonizing course design and classroom activities. A discussion of how to apply and adapt the author's methods for different courses, programs, and local contexts leads to critical reflection on the impact of these changes on student learning and their efficacy in terms of decolonization itself.
\end{abstract}

\section{Résumé}

Les établissements universitaires canadiens continuent de faire face à la décolonisation. Il est particulièrement difficile à transformer la théorie (tel que celles de la décolonisation et de la colonialisme de peuplement) et les appels à l'action de la Commission de vérité et réconciliation du Canada, en résultats concrets, pratiques et significatifs pour l'instruction académique. Pour aider, l'article présent donne une étude de cas au niveau universitaire: un processus de la décolonisation d'un cours d'analyse de la musique populaire par une instructrice non autochtone. L'article décrit de stratégies pour décoloniser dans la conception et la mise en œuvre des cours. Une discussion sur la façon d'appliquer et d'adapter les méthodes présentées pour autres cours, programmes, et contextes locaux mène à une réflexion critique sur l'impact de ces changements sur l'apprentissage des étudiantes et de l'efficacité de ces changements du point de vue de la décolonisation. 


\section{Introduction}

Many Canadian higher educators had never considered decolonization until 2015, when the Truth and Reconciliation Commission of Canada (TRC) released its final report and its 94 Calls to Action (Truth and Reconciliation Commission of Canada, 2015). The TRC report was not the first time that large-scale calls for decolonization and justice for Indigenous ${ }^{1}$ Peoples in the context of education had been made (Royal Commission on Aboriginal Peoples, 1996; United Nations, 2007), but the TRC's recommendations for higher education sparked new widespread institutional and individual interest in decolonization and Indigenization. Canadian institutions of higher education have responded to the Calls for Action in ways both broad (Universities Canada, 2015) and specific, including writing and speaking land acknowledgments, hiring more Indigenous faculty and staff, establishing or expanding Indigenous student support centres, developing partnerships with local Indigenous communities, hiring or expanding the role of resident Elders and knowledge keepers, establishing or expanding an Indigenous Studies department, and requiring courses on Indigenous knowledge as part of specific degree programs. ${ }^{2}$

Yet there is the danger of treating these Calls to Action as a tokenistic checklist rather than an opportunity for meaningful institutional change. There are also the dangers of placing the burden for decolonizing and Indigenizing higher education onto Indigenous Peoples by asking them to lead the change, and of knowingly or unknowingly appropriating Indigenous knowledge and pedagogies for use in colonial institutions in a way that is recolonizing rather than decolonizing (Hill, 2012; Kuokkanen, 2010; Mihesuah \& Wilson, 2004). The TRC report is clear that decolonization is the responsibility of all educators, not just Indigenous ones, and that tokenistic gestures will not meet the criteria for change. It follows, then, that decolonization must occur in every discipline, not just in Indigenous Studies, and must be a meaningful act.

However, moving beyond a checklist to the specifics of how to take meaningful action as a settler (non-Indigenous) faculty member is challenging. A few case studies exist (Iseke-Barnes, 2008; Louie, Poitras-Pratt, Hanson, \& Ottman, 2017), but resources are scarce. This paper presents a discussion of a specific instance of decolonization by a settler instructor in a particular context in order to inspire reflection and action on the part of other settler instructors grappling with the task ahead. The methods to be discussed will not present a clear pathway toward decolonization, nor will they serve as a checklist of best practices or principles. Rather, the paper outlines a variety of possible steps that settler instructors could take as they decolonize their courses, and further, makes visible the deep self-reflection necessary to take those steps meaningfully and ethically.

\section{What Is Decolonization?}

Some of the difficulty in developing specific actions for decolonization in higher education comes from the fact that the term decolonization is complex, with different scholars articulating diverse and sometimes contradictory definitions. Fanon (1963) and other postcolonial theorists often write about decolonization in the context of places where the colonizers have left, whether by choice or by force, which is a context that has some, but not total, relevance for Canada. Numerous settler-colonial theorists (Battell Lowman \& Barker, 2015; Mackey, 2002; Veracini 2010; Wolfe, 2006) take the notion of decoloniza- 
tion into places such as Canada, the United States, Australia, and New Zealand, where Indigenous Peoples face an invasion of settlers that has not ceased. To decolonize in a settler-colonial context, Battell Lowman and Barker (2015) argue that three "main pillars" must be addressed: that settler invasion is an ongoing and institutionalized structure rather than a single event (that is, an activity that takes place in the present as well as the past); that settlers intend to stay in the colonized lands rather than return home; and that the end goal of settler colonialism is the elimination of Indigenous Peoples (Battell Lowman \& Barker, 2015, pp. 25-26).

The second of Battell Lowman and Barker's pillars (the fact that settlers have no intention to return home) brings particular complexities to the task of decolonization in a settler-colonial context. Decolonization might not, therefore, mean that settlers return all lands to Indigenous Peoples and leave for their countries of origin. Yet Tuck and Yang (2012) insist that decolonization is fundamentally rooted in land repatriation, and that land itself must be conceived not in settler terms but Indigenous ones, stating that decolonization "must involve the repatriation of land simultaneous to the recognition of how land and relations to land have always already been differently understood and enacted" (p. 7). When faced with a potential decolonial ultimatum of land repatriation, settler instructors might balk from taking any intermediate steps, however small, or might not even recognize that there are intermediate steps that can be taken.

Mi'kmaw scholar Marie Battiste (2013) offers a different definition of decolonization, one that might leave room for these intermediate steps toward decolonization. Writing in terms of decolonizing education specifically, Battiste (2013) compares colonialism to a strong river current:

This imperialistic system of knowledge that is considered the "mainstream" functions like a "keeper" current in a rapidly flowing river or ocean. The keeper current drags a person to the bottom and then to the top, but if one fights against the current one usually drowns. (p. 107)

However, Battiste (2013) offers a way forward out of this seemingly impossible situation, continuing:

Decolonization then is a process of unpacking the keeper current in education: its powerful Eurocentric assumptions of education, its narratives of race and difference in curriculum and pedagogy, its establishing culturalism or cultural racism as a justification for the status quo, and the advocacy for Indigenous knowledge as a legitimate education topic. (p. 107)

I use Battiste's (2013) theorization to interpret decolonization as having two parts: first, uncovering Eurocentric elements in the specific context where decolonization will happen, and second, finding ways to put Indigenous and settler knowledge on an equal footing in terms of both content and pedagogy. The first task involves deep consideration of numerous contextual factors, both at the level of the course (discipline, position in program, and student and instructor identities and power relationships) and at the level of the institution (geographic location, interest and method of decolonization, student population, and availability of resources and support). Instructors also must consider 
Eurocentric elements in terms of local and cultural power dynamics and the relationships among the instructor, the institution, and Indigenous Peoples. The second task of decolonization-putting Indigenous and settler knowledge on an equal footing-is what is often termed Indigenization.

Just as settler colonialism has existed for centuries and continues today, decolonization is also the work of multiple lifetimes. In the context of a single course, decolonization cannot be completed in a single iteration: It is a process, not a product. But this does not mean it cannot be completed at all. In the remainder of this paper I will discuss an upperlevel undergraduate course on popular music that I have worked to decolonize. I will describe both successes and challenges in my approach and offer motivation for readers to decolonize in their own local contexts.

\section{Exposing Colonialism and Eurocentricism in Music Theory}

Understanding and acknowledging the ways in which a discipline is colonial and Eurocentric is a complicated endeavour. However, there is a danger of spending so much time on this first task that decolonizing action and change never happen. The comments that follow are deliberately broad and informal observations rather than deep research grounded in extensive evidence. At times I will generalize and even stereotype my home discipline in order to find points of immediate action. I recognize that my home discipline has many nuances that are lost in this discussion, and which could inform additional points of change, but given the enormity and urgency of the task of decolonization, it is important to begin with the basics rather than delay for the sake of a more comprehensive investigation.

Music theory as it is practised in Canadian universities typically involves trying to understand how a particular piece of music is put together, how patterns of sound might lead to particular interpretations, and how compositional trends might manifest themselves in the work of a single composer or in the work of many composers over time. In many ways, the field is akin to disciplines such as literature and art history in which a text is subject to analysis or close reading. In the case of music theory, the text is music.

Music theory is taught almost exclusively in the context of Bachelor of Music (BMus) programs, and so it is important to understand the Eurocentric context of the degree and the broader field. European curricular models dating back to the 19th century form the basis of most BMus programs in Canada, the United States, and Europe (Rideout, 1990). In terms of repertoire, most BMus programs focus mainly on what is referred to as "classical music" in common parlance and what music scholars might define more precisely as Western European art music mostly written between the 18th and 20th centuries (West Marvin, 2012). Even before they enter a BMus program, students are expected to be able to read Western European music notation, play Western European musical instruments, and understand the basics of Western European ideas about the nature of musical sounds (often referred to as "the elements of music"), as well as use standard music listening strategies for this repertoire. The four-year BMus program focuses on deepening these skills. While there has been a push in the last few years toward expansion and diversification of this standard curriculum (College Music Society, 2014; Moore, 2017; Sarath, Meyers, \& Shehan Campbell, 2017), it remains unclear how much this has changed institutional programs or individual teaching practices. It is my sense that responses to these conversations have come more in the realm of repertoire than in analytical or epis- 
temological approach; that is, broadening the content without questioning the analytical lenses applied to it or the people who are invited to apply them.

Given this Eurocentric context for BMus programs generally, it is no surprise that music theory itself is similarly Eurocentric. While the discipline is broadening in terms of its repertoire focus, classical music remains at its centre. Furthermore, the epistemological and methodological orientation of the discipline, its "ways of knowing and doing," are firmly rooted in a European orientation (Bent \& Pople, 2001; Christensen, 2002) that privileges written forms of communication, particularly Western European music notation (Cook, 2014). Yet the discipline mostly takes as given these colonial elements and Eurocentric orientations. Questions of decolonization and Indigenization have entered music theory's disciplinary conversations about curricula only once to my knowledge (Douglas, 2010), although many Canadian music departments and professional societies are beginning to discuss it informally.

One broad area for decolonizing music theory, then, has to do with recognizing the colonial origins of the discipline. Making these elements visible to students could be as simple as a change in course title ("Western European Art Music Theory I" or "The Materials of Western European Art Music I" rather than "Music Theory I" or "The Materials of Music I"), or could be addressed through verbal or written statements in the classroom, on a syllabus, or as part of an assignment description. But there are many actions instructors can take within a course that can provide more meaningful decolonization, even in a discipline as rooted in colonial and Eurocentric practices as music theory. The following discussion of decolonial actions undertaken in the design and implementation of an upper-year seminar on popular music analysis provides a detailed example.

\section{Decolonization in a Popular Music Analysis Course}

I will employ a narrative or storytelling format for discussion of my decolonizing course revisions. Numerous Indigenous scholars (Archibald, 2008; Armstrong, 2013; Davis, 2014; King, 2003; Kovach, 2009; Tuhiwai Smith, 2012) have discussed the importance of stories and storytelling as a research method or discursive strategy. However, at the time when I taught this course and wrote the first drafts of this paper, I was unaware of this work; put another way, I was at a different place in my decolonization journey. Instead, I drew inspiration from settler scholars in my home discipline of music theory who have used narrative structures to challenge disciplinary discursive norms for purposes other than explicit decolonization (Kielian-Gilbert, 1994; Korsyn, 2003; Krebs, 1999). Storytelling is also an integral part of my own family's culture, thanks to my mother who wove magical tales for my siblings and me on every long car ride and who has made picture books come alive for generations of preschool children in my hometown. In this paper, a narrative structure will allow readers to see the stages and steps in my process of decolonization, further emphasizing that it is a journey rather than a finished product.

When I proposed a special topics course on popular music analysis to my department chair, I knew that decolonization would also be a part of the course. Therefore, at the beginning of my course design process, I met with Indigenous staff and faculty on campus. In my small campus context, this entailed meeting with an Indigenous Support Services coordinator and an Indigenous colleague from another department. While neither was an expert in my discipline, those conversations did shape my thinking as I considered other 
aspects of course design. In the context of my typical course design practice, this change was a significant step toward decolonization, since I had never before thought to consult with Indigenous people as I prepared a discipline-specific course. Now I consider it a fundamental starting point, a manifestation of the maxim "Don't do anything about us without us." In future courses, I would build on these relationships, and work to forge additional relationships with Indigenous musicians that could shape course design further.

As I brainstormed other course design elements, I considered the degree to which I wanted to make decolonizing practices visible to students. I chose not to mention some of my strategies to students, while I clearly identified others as "decolonizing music theory." For this course, having students grapple with the topic of decolonization in music theory at the same time as they grappled with analytical methods was an informal goal. I did not design any formal learning outcomes related to decolonization, nor did I ever assess it, although that might be a consideration for future iterations.

My choice of course content was a major site for decolonization. In North American music theory courses, the musical repertoire (the "texts" that will be analyzed) is an important component of content. Given that my repertoire for this course was popular music, I had the potential to shatter my discipline's typical Eurocentric focus on Western European classical music, or at least to critique it, since popular musicians come from a range of identities and cultural backgrounds. However, music theory courses in Canada and the United States and academic research both typically focus on genres with close ties to Western European musical norms and white male musicians (despite the recognition that the genre does feature a blend of cultural traditions in its history).

To counter this lack of diversity, I used a different winner from the Polaris Music Prize as the focus for each of the six units in the course. The Polaris Prize is awarded annually to a Canadian album released in the preceding year, and both the prize's initial longlist and its final winners include a remarkable amount of diversity by many measures. Diversifying does not equate with decolonizing and Indigenizing, but in the case of the Polaris Prize, Indigenous artists feature prominently, making it easy for me to choose Indigenous artists for two of the six course units. The prize's perception as an "indie" music award, despite the claim in its mission statement to award prizes without regard to genre (Polaris Music, n.d.), also raises questions about the validity of genre categories in music more broadly. While answering such questions was outside the scope of the course, this situation did introduce some ambiguity that was helpful in terms of unsettling expectations and norms.

I thus increased Indigenous content in terms of repertoire, but this still left the second half of music theory course content: analytical approach. Given the historical orientation of the discipline as described previously, it is no surprise that Eurocentric analytical methods and ways of thinking about music (including the definition of what it means to analyze music in the first place) are the often-unspoken norm in the discipline. I paired six different analytical methods with each of my artist-focused units, and all but one method was based on standard analytical practices in my field. In remaining mostly true to Eurocentric analytical practice and epistemology, I did not escape a Eurocentric focus, but I was able to expose this colonial focus to students through critical discussions at the end of each unit. I set the tone with the opening classes of the semester, where students read and discussed texts on systems of music transcription and notation. This exposed the commonly held fallacy of Western European music notation as the only form of music notation and annotation of the 
score as the only form of music analysis. It also led to broader questions about the purpose of notating music and sounds and the benefits and drawbacks of doing so. Such discussions are sometimes present in research articles in the field of popular music analysis, but are rarely, if ever, connected to notions of Eurocentricism and decolonizing practices.

My typical pedagogical style in the course also played a role in my decolonization efforts, although my teaching style was developed long before I knew of the existence of the term decolonization, and might just as easily be labeled as "democratizing" or "learnercentred" rather than "decolonizing." I deliberately fostered student agency and choice over certain aspects of their learning, because at the time I had an informal understanding of decolonization as rebalancing power relationships of all kinds, and I wanted to begin to rebalance the power relationship between me and my students. I let students take control over a portion of their grade for the course by asking them to justify and assign their own participation grades (worth $15 \%$ of their final grade). I physically decentred my authority in the classroom by arranging desks in a circle rather than in rows toward a podium. I asked students to participate in their own learning through the use of active learning strategies throughout the semester; with a small class of seven this was easy to achieve, but authors including Allen and Tanner (2005) and Kerr (2011) have discussed how to use active learning strategies effectively in large-enrollment courses. A deeper question that I continue to ponder is the degree to which pedagogies enacted by a settler instructor can truly be considered decolonizing: If the instructor is not ceding power and space to Indigenous Peoples, if there is no Indigenous voice or physical presence in the classroom, is decolonization happening? On the other hand, my attention to student agency and choice reveals that I was thinking more about power relationships in the classroom than I would have been if I were not intentionally seeking to decolonize, which is an important first step.

I used several strategies to make decolonization explicit for students. These strategies may seem either simplistic or revolutionary to readers depending on their own unique histories, disciplinary affiliations, and institutional contexts. Informally considering my discipline of music theory, all of these strategies would likely be considered revolutionary, or possibly outside the realm of the discipline ("that's not music theory" is a charge I can imagine being levelled against some of these examples). This is part of why decolonization must be done with attention to specific local contexts and conventions: what is cutting-edge for me in my discipline might be commonplace for someone else, or vice versa.

I included my institution's territorial acknowledgment on the first page of my syllabus, and read it out on the first day, moving beyond a tokenistic gesture to describe my personal sense of being a guest on the land of others during a recent powwow. ${ }^{3}$ I discussed settler/Indigenous issues in the two units of the course in which Indigenous musicians were featured (Buffy Sainte-Marie, Piapot Plains Cree First Nation; and Tanya Tagaq, Inuk). This choice might appear to be problematic because I talked about Indigenous issues with Indigenous artists and did not talk about specific issues tied to the identities of other artists (for instance, women's issues with female musician Feist). In both cases, however, the artists led me to the topics through their work, since both Sainte-Marie and Tagaq forefront such concerns in their art. I was also attentive to the way I presented these two units, placing them at different places in the semester rather than leaving them for the end, and maintaining a focus on music analysis (rather than political advocacy) to the same degree as the settler artists featured in other units. Since both artists participate 
in the capitalist system of commercial pop music by selling their albums publicly and charging admission for live concerts, I felt no concerns about including their music in a classroom setting; however, other Indigenous musical genres would require different approaches (Palmer, 2007).

In the unit on Buffy Sainte-Marie, the overall analytical consideration was on theories of interaction between words and music. My students and I analyzed Sainte-Marie's lyrics in terms of researcher identity and knowledge, discussing what we as analysts knew and did not know about the historical events Sainte-Marie describes in songs such as "Bury My Heart at Wounded Knee" and "Now That the Buffalo's Gone," and how that might impact the way we listened to and analyzed her work. I took a class period to let Sainte-Marie speak for herself by showing a video of a lecture she'd given at the Canadian Museum for Human Rights (Sainte-Marie, 2016). Then, I facilitated a class analysis of a spoken-word performance Sainte-Marie gave within the lecture. By engaging with the video as an artwork in itself, I validated the importance of Sainte-Marie's lecture in terms of the learning outcomes of the course, rather than treating the video as a fun diversion from the course's primary content.

In the unit on Tanya Tagaq, I began by teaching students about katajjaq, a practice often translated as throat singing or throat games, found in communities across the eastern Canadian Arctic and typically enacted by two women (Cavanagh, 1976; Nattiez, 1983). Tagaq's practice is derived from katajjaq, although it is not the same thing (Nelles, 2015; Przybylski, 2016). My discussion of katajjaq brought new Indigenous musical content into the course, but my approach was also important. Rather than treating Western $\mathrm{Eu}-$ ropean music as the norm and katajjaq as the exotic "Other," a view many of my students tended to express in class discussions, I talked about and modeled ways to place the two music cultures on equal ground, starting by simply identifying my colonial listener tendency to exoticize non-Western music. I also took Tagaq's strong public advocacy for particular issues, such as climate change and missing and murdered Indigenous women and girls, as the starting point for the musical analyses we explored as a class, expanding notions of what it means to analyze music in the first place.

These various actions would have presented my students with a music theory course far more decolonized than current undergraduate textbooks would suggest is common in my discipline. However, I wanted to make decolonization a visible course theme. Midsemester, I took a 90-minute class period to consider with my students what colonial and decolonial practices in music theory might look like. I deliberately positioned this class halfway through the semester, at a point when there was considerable trust and rapport among the group. Two days before the class meeting, I asked students to prepare thoughts on four questions: (1) "What does it mean to colonize?" (2) "What does it mean to decolonize?" (3) "What are some colonial practices of music theory?" (4) "How could we remove those colonizing practices?" I also assigned each student a particular relationship (e.g., "the relationship between humans and nature," "the relationship between music and sound," or "the relationship between music and spirituality/religion") to try to uncover what a Western approach to that relationship might be. These preparatory exercises were all informal and no-stakes reflections rather than deep or research-based critiques that would be graded.

I had some general themes in mind for the discussion on the day itself, including con- 
necting the discussion of colonization and decolonization to music theory and analysis, but I deliberately left the class time open to allow in-the-moment conversations to shape the class. To guard against any student responses that "this isn't music theory," I gave a short opening speech framing the class within the context of broader disciplinary discussions on race and gender, explaining to students the ways in which my professional society had engaged with issues related to decolonization without addressing decolonization itself. We spent the bulk of our time with the first discussion question, considering the difference between colonization and decolonization. Students worked together at the classroom's two blackboards to brainstorm both general responses and the ways the terms might apply to music theory specifically, and I allowed them to work together without my input before we sat in a circle to discuss as a group. In retrospect, this class period was a critical moment that helped the class prepare for the unit on Tanya Tagaq at the end of the semester.

My final example of decolonizing practices resulted from a private interaction with an international student in my course. In her final paper, the student wanted to draw a connection between Colombian-Canadian musician Lido Pimienta's music and what the student described as "powwow" music, a connection I believed to be unfounded. I struggled to shape our conversations in a way that respected my student's cultural background and her stage of learning about Canada's historical and present-day engagement with Indigenous Peoples, but that also deepened her understanding of decolonization and the dangers of asserting superficial cultural connections in a musical analysis. A year later, I believe the best strategy would have been to focus on music theory's disciplinary practices and to ask the student to produce clear musical evidence that would demonstrate a similarity or influence. At the time, I tried to be open to her views, but found myself constantly fighting an instinct to shut down her ideas entirely as "not politically correct." I realized through this encounter that decolonization changes dramatically depending on the students in the classroom, and that my own instincts are not always appropriate. As I have learned more about understandings of decolonization in a global context, I am increasingly sensitive to the possibility that international students can face a sort of colonization when they study abroad, and in future teaching and research I intend to investigate this possibility more deeply.

The preceding discussion of decolonizing a course may appear to be unreproducible, rooted as it is in a single discipline, institution, instructor, and student group. However, while the context is specific, the strategies are not. Below is a list of generalized strategies used in decolonizing my course, listed in the order in which they occur in the text above. This list of strategies is not exhaustive, but it does begin to meet the demand for specific ways of decolonizing that address the TRC's Calls to Action.

- Read/teach key texts in decolonization and settler-colonial theory.

- Uncover colonial/Eurocentric elements of a discipline.

- Expose colonial/Eurocentric elements of a discipline (to colleagues and students).

- Meet with Indigenous people and resource centres on campus.

- Consider incorporating decolonization into a learning goal or learning outcome.

- Consider whether to assess students' learning in terms of decolonization.

- Include Indigenous course content (videos, readings, music, etc.).

- Broaden and/or critique disciplinary approaches to content. 
- Teach diverse ways of knowing rather than one single (Eurocentric) way of knowing.

- Connect classroom teaching strategies to decolonization.

- Consider power relationships in the classroom.

- Consider local context (geography, institution, department, students, classroom space).

- Include a territorial acknowledgment on the syllabus; explain it and speak it on the first day of class and later in the semester as appropriate.

- Let Indigenous perspectives (whether general or individual) guide approaches to course content.

- Place Indigenous and Eurocentric knowledge on equal footing and make that decision transparent for students.

- Discuss Indigenous/settler issues within a discipline.

- Discuss the implications of colonization/decolonization for a discipline.

- Consider the multiple and intersectional identities present among students and faculty.

\section{Reflections on the Incomplete Process of Decolonization}

I do not want to claim my course is a total success in decolonization, as there are many ways my work could be critiqued. Most fundamentally, my course did nothing to return any land to the Mi'kmaq Peoples upon whose territory my then-institution rests, nor did I ever discuss the idea of land repatriation with my students. Almost as problematic is the fact that a settler led the entire course and there were no Indigenous people physically present in the classroom through the entire semester.

I worked to expose Eurocentric aspects of my discipline, and explored multiple perspectives on music analysis with my students. Two of the six units focused on Indigenous musicians, and Indigenous issues featured prominently at multiple times in the course. However, none of the course readings were by Indigenous authors, and none of the analytical methods were Indigenous approaches to music or analysis. The fundamental lens through which we discussed music analysis, and music itself, continued to be a Western European one.

There were times when decolonization was too uncomfortable, and I backed away. A colleague gave me the contact information for a local Indigenous drummer who might be willing to serve as a guest speaker, but, having already contacted two people I had never previously met-the campus Indigenous coordinator and a community Elder-I had reached my limit in terms of stepping outside my comfort zone, and never followed up. With a year's perspective, I see this moment as a clear example of my colonial white settler privilege, in that these identities give me the power to control my own level of discomfort and to face no consequence when I back away.

This comment leads to the importance of self-reflection and self-analysis in decolonization efforts. I am, by nature, a reflective person who is willing to consider decolonization of a course and of myself at a deep level. I am also fairly self-aware in terms of my own risk tolerance. Instructors who are not so innately reflective will need to build time into course design and implementation to consider the degree of risk (both professional and personal) they are willing to take as they make changes to their courses. When considering the degree of risk, however, I would caution settlers not to become too complacent. Tuck and Yang (2012), building on Mawhinney (1998), describe various settler "moves to innocence" as "those strategies or positionings that attempt to relieve the settler of feelings 
of guilt or responsibility without giving up land or power or privilege, without having to change much at all" (p. 10). In a related vein, Battell Lowman and Barker (2015) describe settler "moves to comfort" as ways of avoiding responsibility and action by "proving-if only to ourselves-that we are doing everything we can and therefore have nothing to feel bad about, really" (p. 99). Decolonization is the responsibility of every settler, and with that responsibility comes discomfort. To me, such discomfort is a small price to pay for the genocide inflicted upon Indigenous Peoples in the country I call Canada since European contact (Truth and Reconciliation Commission of Canada, 2015).

In sharing my struggles with decolonization, I do not wish to suggest that this whole endeavour was a failure. Rather, I want to be clear that there is a long way to go before we can claim that a course or a program has been "decolonized." It is a process, not a product, and I take inspiration from Battell Lowman and Barker (2015) who write that "well-intentioned Settler Canadians must be driven to seek discomfort or risk falling into complacency and self-congratulations for hard work already done, missing the vast struggle that remains before us" (p. 106). In this paper, I can claim that I began the process of decolonization, but I must also acknowledge that there is much more for me to do.

\section{Conclusion}

Since I did not make decolonization an explicit learning outcome, I have little concrete evidence that my strategies were effective in terms of student learning and growth. In a future study, I hope to measure this more explicitly, while recognizing that decolonization is a personal and individual process of change that is difficult to measure. For the course discussed in this paper, I have evidence that I prompted my students to take steps on their own decolonizing journeys. On the last day of the course, I asked students to write anonymous responses to the question "What did you learn in this course?" I told them that the learning they addressed could relate to course content or to themselves. Of the six responses, two mentioned the Indigenous content specifically, which I think is significant given that they were not prompted to do so. One student wrote:

This, along with the Music in Canada class, was the first time I've ever had a course that talked about Indigenous issues. This seems to be especially rare in music courses so I feel like that aspect was super important for my overall education. (Personal communication, 30 November 2017)

Another student wrote:

I've also learned much more than music in this class; we've focused on indigenous [sic] issues and other current [sic] issues which is new for theory! (for me). (Personal communication, 30 November 2017)

The students in this course shaped this work immensely. I am grateful that they enthusiastically engaged with my teaching style, the course content, and the numerous non-traditional class activities and discussion topics I presented to them. My efforts at decolonization would have been far more challenging if I had encountered resistance in the classroom, a resistance I felt the following semester when I worked to decolonize firstand second-year required music theory courses. These seven women were active partners 
in the effort to decolonize this popular music class, and I could not have done what I did without them. As both Indigenous and settler educators continue on their journeys into decolonization, we must remember that we are always bringing others along with us. By sharing our individual journeys and individual efforts, we will inspire and teach others and collectively bring about much-needed institutional change.

\section{Endnotes}

1 In this paper, I follow current academic and United Nations practice and use the term Indigenous to refer to the First Peoples in the land I know as Canada. However, I recognize that this term is a generalization of a diverse group of people and that individuals have the right to name their own identities.

2 For a comprehensive list of institutional strategies for decolonization, see Pete (2016).

3 At the time I taught this course, I understood myself to be a guest on Indigenous lands. I have since learned that such a characterization is inaccurate, and would now describe myself as an uninvited guest or, in the case of the powwow, as a visitor. However, I have preserved the term guest in the main text to highlight my position at the time within an ongoing process of decolonization.

\section{References}

Allen, D. \& Tanner, K. (2005). Infusing active learning into the large-enrollment biology class: Seven strategies from the simple to the complex. Cell Biology Education 4(4): 262-268. doi:10.1187/cbe.05-08-0113

Archibald, J. (2008). Indigenous storywork: Educating the heart, mind, body, and spirit. Vancouver: University of British Columbia Press.

Armstrong, H. (2013). Indigenizing the curriculum: The importance of story. First Nations Perspectives 5: 37-64. Retrieved from http://mfnerc.org/wp-content/ uploads/2013/04/Section3_Indigenizing-the-Curriculum-The-Importance-of-Story.pdf

Battell Lowman, E., \& Barker, A. (2015). Settler: Identity and colonialism in 21st century Canada. Black Point, NS: Fernwood Publishing.

Battiste, M. (2013). Decolonizing education: Nourishing the learning spirit. Saskatoon, SK: Purich Publishing.

Bent, I. \& Pople, A. (2001). Analysis. In Grove Music Online. Oxford, England: Oxford University Press. doi:10.1093/gmo/9781561592630.article.41862

Cavanagh, B. (1976). Some throat-games of Netsilik Eskimo women. MUSICultures 4: 43-47. Retrieved from https://journals.lib.unb.ca/index.php/MC/article/view/21875

Christensen, T. (Ed.). (2002). The Cambridge history of Western music theory. Cambridge, England: Cambridge University Press.

College Music Society. (2014). Transforming music study from its foundations: A manifesto for progressive change in the undergraduate preparation of music majors. Retrieved from doi:10.18177/sym.2016.56.fr.11118

Cook, N. (2014). Beyond the score: Music as performance. New York, NY: Oxford University Press. 
Davis, J. (2014). Towards a further understanding of what Indigenous people have always known: Storytelling as the basis of good pedagogy. First Nations Perspectives 6: 83-96. Retrieved from http://mfnerc.org/wp-content/uploads/2014/10/Towards-aFurther-Understanding.pdf

Douglas, G. (2010, November). Decolonizing music theory: Some thoughts from outside the field. Paper presented at the 33rd annual meeting of the Society for Music Theory as part of the Committee on Diversity's special session "Addressing ethnic and racial diversity in music theory," Indianapolis, IN.

Fanon, F. (1963). The wretched of the earth. New York, NY: Grove Press.

Hill, E. (2012). A critique of the call to 'always Indigenize!' Peninsula 2(1). Retrieved from https://journals.uvic.ca/index.php/peninsula/article/view/11513/321

Iseke-Barnes, J. M. (2008). Pedagogies for decolonizing. Canadian Journal of Native Education 31(1): 123-148.

Kerr, A. (2011). Teaching and learning in large classes at Ontario universities: An exploratory study. Toronto: Higher Education Quality Council of Ontario. Retrieved from http://www.heqco.ca/SiteCollectionDocuments/Teaching\%20and\%20Learning\%20 in\%20Large\%20Classes\%20ENG.pdf

Kielian-Gilbert, M. (1994). Of poetics and poiesis, pleasure and politics-Music theory and modes of the feminine. Perspectives of New Music 32(1): 44-67. doi:10.2307/833151

King, T. (2003). The truth about stories. Toronto, ON: House of Anansi Press.

Korsyn, K. (2003). Decentering music: A critique of contemporary musical research. New York, NY: Oxford University Press.

Kovach, M. (2009). Indigenous methodologies: Characteristics, conversations, and contexts. Toronto, ON: University of Toronto Press.

Krebs, H. (1999). Fantasy pieces: Metrical dissonance in the music of Robert Schumann. New York, NY: Oxford University Press.

Kuokkanen, R. J. (2010). Reshaping the university: Responsibility, Indigenous epistemes, and the logic of the gift. Vancouver, BC: University of British Columbia Press.

Louie, D. W., Poitras-Pratt, Y. P., Hanson, A. J., \& Ottman, J. (2017). "Applying Indigenizing principles of Decolonizing Methodologies in university classrooms." Canadian Journal of Higher Education 47(3): 16-33. Retrieved from http://journals. sfu.ca/cjhe/index.php/cjhe/article/view/187948

Mackey, E. (2002). The house of difference: Cultural politics and national identity in Canada. Toronto, ON: University of Toronto Press.

Mawhinney, J. (1998). 'Giving up the ghost': Disrupting the (re)production of white privilege in anti-racist pedagogy and organizational change (Master's thesis). Ontario Institute for Studies in Education of the University of Toronto, Toronto, ON. Retrieved from http://www.collectionscanada.gc.ca/obj/s4/f2/dsk2/tape15/PQDD_ooo8/MQ33991.pdf

Mihesuah,D.A.\&Wilson,A.C.(Eds.).(2004).Indigenizing the academy: Transforming scholarship and empowering communities. Lincoln, NE: University of Nebraska Press. 
Moore, R. D. (2017). College music curricula for a new century. New York, NY: Oxford University Press.

Nattiez, J.-J. (1983). Some aspects of Inuit vocal games. Ethnomusicology 27(3): 457-475. doi:10.2307/850655

Nelles, D. (2015). Howl: Why Tanya Tagaq sings. The Walrus (January/February). Retrieved from http://www.thewalrus.ca/howl

Palmer, A. D. (2007). Approaching a sacred song: Toward a respectful presentation of the discourse we study. Studies in American Indian Literatures 19(2):52-61. doi:10.1353/ ail.2007.0018

Pete, S. (2016). 100 Ways: Indigenizing and decolonizing academic programs. Aboriginal Policy Studies 6(1): 81-89. doi:10.5663/aps.v6i1.27455

Polaris Music.(n.d.).About. Retrieved March 10, 2019, from https://polarismusicprize. ca/about/

Przybylski, L. (2016, September 8). Throat singer Tanya Tagaq loudly combats Indigenous stereotypes. KCET. Retrieved from https://www.kcet.org/shows/artbound/ tanya-tagaq-nanook-of-the-north-throat-singer

Rideout, R. (1990). The German model in music curricula. College Music Symposium 3o(2): 106-111. Retrieved from https://www.jstor.org/stable/40374047

Royal Commission on Aboriginal Peoples. (1996). Report of the Royal Commission on Aboriginal Peoples. 5 vols. Ottawa, ON: Canada Communication Group. Retrieved from https://www.bac-lac.gc.ca/eng/discover/aboriginal-heritage/royal-commissionaboriginal-peoples/Pages/final-report.aspx

Sainte-Marie, B. (2016, October 5). An evening with Buffy Sainte-Marie. Public lecture at the Canadian Museum for Human Rights, Winnipeg, MB. Retrieved from https://www. youtube.com/watch?v=CYZhjgLjUtI

Sarath, E., Meyers, D., \& Shehan Campbell, P. (2017). Redefining music studies in an age of change: Creativity, diversity, and integration. New York, NY: Routledge.

Truth and Reconciliation Commission of Canada. (2015). Honouring the truth, reconciling for the future: Summary of the final report of the Truth and Reconciliation Commission of Canada. Winnipeg, MB: Truth and Reconciliation Commission of Canada. Retrieved from https://nctr.ca/assets/reports/Final\%20Reports/Executive_Summary_ English_Web.pdf

Tuck, E., \& Yang, K.W. (2012). Decolonization is not a metaphor. Decolonization: Indigeneity, Education, and Society 1(1): 1-40. Retrieved from https://jps.library. utoronto.ca/index.php/des/article/view/18630

Tuhiwai Smith, L. (2012). Decolonizing methodologies: Research and Indigenous peoples (2nd ed). London: Zed Books.

United Nations. (2007). Declaration on the rights of Indigenous peoples. UN Doc. A/61/L. 67 . 
Universities Canada. (2015). Universities Canada principles on Indigenous education. Retrieved from https://www.univcan.ca/media-room/media-releases/universitiescanada-principles-on-indigenous-education/

Veracini, L. (2010). Settler colonialism: A theoretical overview. London, England: Palgrave Macmillan.

West Marvin, E. (2012). The core curricula in music theory: Developments and pedagogical trends. Journal of Music Theory Pedagogy 26: 255-264. Retrieved from https://jmtp.appstate.edu/core-curricula-music-theory-developments-and-pedagogical -trends

Wolfe, P. (2006). Settler colonialism and the elimination of the native. Journal of Genocide Research 8(4): 387-409. doi:10.1080/14623520601056240

\section{Contact Information}

Robin Attas

Centre for Teaching and Learning

Queen's University

robin.attas@queensu.ca

Robin Attas is a settler (British/Greek) educational developer in the Centre for Teaching and Learning at Queen's University on Anishinaabe and Haudenosaunee territory. She supports faculty, staff, and students on a range of topics including writing pedagogy, course design, and decolonizing the curriculum. Prior to her current position, she held faculty positions in music theory at Mount Allison University and Elon University, and maintains an affiliation with the Dan School of Drama and Music at Queen's University. Her research interests include decolonizing and Indigenizing the curriculum generally and in music theory specifically, improving methods for supporting non-Indigenous faculty interested in taking steps toward decolonization, decoding the disciplines, writing across the curriculum, and analyzing rhythm, metre, text, and form in popular music. 